\title{
Examining trading strategies using trend following indicators for Indonesian stock market
}

\section{Dedhy Sulistiawan*, Felizia Arni Rudiawarni and Yie Ke Feliana}

\author{
Accounting Department, \\ University of Surabaya, \\ Jl. Raya Kalirungkut \\ Surabaya, 60293, East Java, Indonesia \\ Email: dedhy@staff.ubaya.ac.id \\ Email: felizia@staff.ubaya.ac.id \\ Email: yiekefeliana@staff.ubaya.ac.id \\ ${ }^{*}$ Corresponding author
}

\begin{abstract}
This study aims to examine the reliability of the technical analysis (TA) approach in Indonesian stock exchanges, specifically moving-average trading rule to determine buy/sell signals. Using ten-year data from 2008-2017, our study examines various exponential moving average (EMA) lengths ranging from shorter duration to longer duration. After considering transaction fee, the findings indicate that EMA are profitable indicators in Indonesian stock markets. Furthermore, this study also finds that higher (lower) return are produced by longer (shorter) EMA lengths. These results contribute to international investors for country-picking strategy including trading strategy in emerging markets.
\end{abstract}

Keywords: technical analysis; exponential moving average; trend following indicator; trading strategy.

Reference to this paper should be made as follows: Sulistiawan, D., Rudiawarni, F.A. and Feliana, Y.K. (2020) 'Examining trading strategies using trend following indicators for Indonesian stock market', Int. J. Trade and Global Markets, Vol. 13, No. 1, pp.52-60.

Biographical notes: Dedhy Sulistiawan is an Associate Professor at Faculty of Business and Economics, University of Surabaya. His research interest is market-based research and behavioural finance/accounting. He has published books and papers in international journals.

Felizia Arni Rudiawarni is an Assistant Professor at Faculty of Business and Economics, University of Surabaya. She is interested in financial accounting, especially in earnings management. She has published papers in several national and international journals.

Yie Ke Feliana is an Associate Professor at Faculty of Business and Economics, University of Surabaya. Her research interest is financial accounting and corporate governance. She has published books and papers in several national and international journals. 
This paper is a revised and expanded version of a paper entitled 'Examining trading strategies using trend following indicators for Indonesian stock market' presented at SIBR 2018 Hong Kong Conference, Hong Kong, 29-30 September, 2018.

\section{Introduction}

The capital market is a means for companies to obtain funding and as well as an investment tool for the investors to allocate their funds in accordance with the needs and preferences of return and risk of each investor. In order to perform its function to allocate funds, it is very important that investors can earn positive return on their investment, otherwise they will choose to get out of the market. When investors decide to invest in equity market, they are exposed to wide variety selection of industrial stocks that make them must analyse many stocks from various industries (Bahri, 2015). In general, when some events occur, market will react quickly to adjust (Gunaasih and Nursasmito, 2015). Therefore, various ways are performed so that investors obtain optimal returns or at least investors do not bear unnecessary risks on their investment.

Various analytical perspectives are discussed by experts so that we can predict future stock prices and make decisions to gain profit or minimise risk. When fundamental analysis focuses on the intrinsic value by considering the economic, financial, and numerous factors affecting future stock prices, technical analysis (TA) is an approach using price and volume data to capture patterns and trends. Both of methods are popular for investors. Related to those strategies, Flanegin and Rudd (2005) present a survey of academicians and practitioners in US, and their research shows that technical analysis is very popular in practice, but it is not considered useful for academician. Conversely, portfolio theory is not considered by practitioners. Although the benefits of TA are still challenged by financial experts, in fact TA is commonly used in the capital market. Many capital market practitioners use TA to define buying and selling strategies in order to gain higher returns than passive strategies. This is also supported by the fact that TA is accessible to practitioners in the form of guidebooks (Pring, 2014), in the form of tools provided by online brokers (e.g., https://www.suretrader.com) and also widely discussed in the online investment forum (e.g., https://stockaholics.net).

TA is usually performed by documenting the capital market activities into chart. Following Elliot's statement on the wave principle, Brown (2012) believes that the market moves in a specific pattern that is called the wave. This wave repeats over time. This wave is believed to represent crowd psychology (the tendency to mimic the behaviour of those around us) where price movements reflect the cycle of market optimism and market pessimism. Technical traders look for the wave pattern and try to exploit the advantage of price movements reflected in the wave.

There are many technical trading strategies, whether individual or combinations of trading rules. Each of these strategies may provide an opposing prediction about future price movements. Of the many trading strategies covered in TA, one of the most interesting is the moving average (MA) strategy. Quite a lot of evidence suggests that the moving average strategy is able to predict the behaviour or pattern of return distribution, although Taylor (2011) believes that the success of this strategy was limited until before 1990. According to Gunasekarage and Power (2001) the use of moving average trading 
rules has predictive ability of market indices in the developed stock markets (UK and US) as well as in emerging markets. And based on their research, the MA strategy provides higher returns than the buy and hold strategy in emerging markets in the South Asian Stock Market.

This study uses MA trading strategy for several reasons. First, the conceptual reason. In TA, there are two approaches: the classical approach and the modern approach. The classical approach emphasises the qualitative data, in which data is described in the form of charts and trends are inferred based on those charts, such as candlestick patterns, head and shoulder patterns and many others chart types/patterns. The classical approach is rarely tested in the academic literature because it is very subjective and hard (if not impossible) to quantify. The modern approach emphasises quantitative data, making it easier to verify and test its objectivity. The most popular modern TA approach is MA strategies. This MA approach is widely used by the stock trading menu, e.g., Yahoo Finance. MA also reaches more attention from academic point of view. Based on the study of Wong et al. (2003), MA is a better strategy than other TA strategies. Second, as MA is the most popular strategies in TA, it is also known as trend following strategies. This means that prices move with the trend. If the investors are not "the market maker", then it is better for them to follow the trends. Market discount everything, so it means all information known by informed investors have been already reflected in price. For individual investors or noise traders, all they need to do is follow the trends and MA strategy support this. Third, previous empirical studies present that MA indicators is useful in building trading system (Wong et al., 2003; McKenzie, 2007).

This study uses Indonesia Stock Exchange (IDX) data. IDX is one of the emerging markets in Asia. Based on data presented by Index Mundi, in 2016, market capitalisation of US stock market is US\$27 trillion. It is the biggest market capitalisation in the world. In the same year, Indonesian stock market capitalisation is only US\$ 426 million (www.indexmundi.com). That number is lower than Singapore, Thailand, and Malaysian stock market. McKenzie (2007) states that technical analysis gives benefit in emerging markets, including Indonesia. Another reason, Fan and Wong (2002) present the data that firms in Indonesia have lower earnings informativeness than other South-East Asia countries. Our study uses technical analysis as an alternative strategy to financial information.

Our study presents that technical analysis is useful in determining time to buy and sell for individual stocks in Indonesian stock market. Using many MA indicators, our results are robust. Technical analysis using MA trading rule generates profit. After considering transaction cost, most of trading strategy using MA indicators still generate profit, except MA five and ten days. Those conditions indicate that overtrading degrades the performance of investors who use shorter trading strategy. After comparing shorter and longer MA strategy, we give evidence that shorter (longer) MA generates lower (higher) return.

Our study gives benefit to trading strategy research in emerging markets. International investors can use the result of this study for country-picking strategy. We also believe that this research contributes to investment communities (foreign or domestic investors) who want to invest their funds in Indonesian stock market.

In discussing our trading strategy research using MA, we explain the theoretical background in Section 2. Data and methodology are provided in Section 3. In Section 4, our paper shows the results and analysis. Conclusion and limitation are presented in the last section. 


\section{Theoretical background}

Trading system is a group of parameters that generate sell and buy signal without ambiguity. In trading system, investors set the formula to buy or sell so that trading system can continue making profit or minimising risk. Buying and selling signals are mostly generated by technical indicators and TA return is determined by the difference between buying and selling price. Specifically, before using TA signals, investors have to determine stock trend by using one of trend following indicators, because one of the basic principles of technical analysis is 'price moves in trend' (Murphy, 1999). This study uses trend following indicator to follow the price movement. Moving average (MA) is the most commonly used by technician for determining trend. It is also used as an indicator in many studies (Brock et al., 1992; Bessembinder and Chan, 1995; Fifield et al., 2005), and McKenzie, 2007)

The MA tries to lessen stock price fluctuations into smoothed trends so that the distortion is reduced to a minimum. Three main types of MA used in technical analysis are: simple, weighted, and exponential MA (Pring, 2014). These MA indicators are also presented in Chart Nexus or Yahoo Finance. MA produces buy and sell signals when the price cuts its average price. Price movement follows trend, which can be up trend or downtrend. When stock prices cross above their average rating from below, this indicates the current price is higher than the previous price and the price is said to be in an uptrend. At this moment buy signals occur. Conversely, if the prices cross below its average value, it indicates that the current price is lower than the previous price and it says that the price is in a downtrend and refers to a sell signal.

This study uses behavioural finance theory, instead of market efficient theory. We believe that price fluctuation is composed by irrational aspect of market participants. TA indicators capture investors behaviour. This signal will help uninformed investor to decide their investment strategies and earn profit (or minimise loss) from the market.

$H_{1}$ : TA indicators using MA signals generate profit.

TA focuses on the market reaction and there are many combinations of indicators that investors could use. It involves a lot of subjectivity from its users. Since MA strategies are trend following indicators, so traders who use MA trading rule should follow the trend. More active traders (less active traders) usually choose shorter (longer) duration of MA and follow on minor (major) trends. For traders who follow the minor trend, they tend to be trapped in over-trading activity. It means that their trading frequency is too high, and it becomes counterproductive to their investment objectives which would end up in lower return or even loss. We propose the second hypothesis:

$\mathrm{H}_{2}$ : TA indicators using longer (shorter) duration of MA result higher (lower) return.

\section{Data and methodology}

Our data consists of ten years of daily stock price listed in Indonesia Stock Exchange (IDX). We use this sample because it represents emerging countries that usually has less efficient market. Some studies (McKenzie, 2007) present that technical analysis is useful in Indonesia. Developing those study, our research uses individual stock rather than index data. 
In the first step, we collect individual stock price data from all public firms in Indonesia from the beginning of 2008 until the end of 2017. We find that among approximately 500 listed firms, only 286 listed firms have transaction from that period. After gathering the complete data, we sort those data based on trading day. Most of individual stocks in Indonesia do not have enough trading day, because it is not liquid market. We select 50 stocks that have the most trading day. When firms do not have trading day, price information and technical analysis signal are less reliable. This condition can produce higher probability of failed signal or unprofitable transaction.

There are many indicators of technical analysis. We select moving average trading rule, because that indicator determines price trend. Understanding the trend is very important to investors. In bullish (bearish) market, price tends to move to higher (lower) level. To convince the results, our study uses several MA, those are: simple moving average (SMA), weighted moving average (WMA), and exponential moving average (EMA). Expanding the depth of results, this research utilises many variation of MA length from 5-day MA until 100-day MA. The step of optimisation is multiples to five, then total MA length used is 20 MA from 5, 10, 15, until 100. SMA formula can be calculated using this equation:

$$
\operatorname{SMA}(n)_{0}=\left(\mathrm{CP}_{0}+\mathrm{CP}_{1}+\mathrm{CP}_{2}+\cdots+\mathrm{CP}_{n-1}\right) / n
$$

$\mathrm{SMA}(n)_{0}$ is simple MA on day 0 using $\mathrm{n}$ period. $\mathrm{CP}_{0}$ is closing price on day $0 . \mathrm{CP}_{1}\left(\mathrm{CP}_{2}\right)$ is closing price on one (two) day before day 0. Symbol $n$ is the length of MA. Developing SMA, we also use WMA. The formula is stated in equation (2).

$$
\operatorname{WMA}(n)_{0}=\left(\mathrm{CP}_{0} \cdot n+\mathrm{CP}_{1} \cdot(n-1)+\mathrm{CP}_{2} \cdot(n-2)+\ldots+\mathrm{CP}_{n} .1\right) /(n .(n+1) / 2)
$$

$\operatorname{WMA}(n)_{0}$ is weighted MA on day 0 using $n$ period. The use of CP and $\mathrm{n}$ is similar to equation (1). Expanding the test, we also use EMA. The formula is presented in equation (3).

$$
\operatorname{EMA}(n)_{0}=\left(\left(\mathrm{CP}_{0}-\mathrm{EMA}_{n-1}\right) \cdot m\right)+\mathrm{EMA}_{n-}
$$

where, $m$ is multiplier that is calculated using $(2 /(n+1))$ and initial $\operatorname{EMA}(n)$ has same number with $\operatorname{SMA}(\mathrm{n})$.

After forming chart of price and MA, buying and selling signals are determined when prices penetrate their MA. Price crosses above (below) a moving average generate buy (sell) signal. Buy signal can be written using $\mathrm{CP}_{t}>\mathrm{MA}_{t}$ when $\mathrm{CP}_{t-1}<\mathrm{MA}_{t-1}$. $\mathrm{MA}_{t}$ $\left(\mathrm{MA}_{t-1}\right)$ is MA value on day $\mathrm{t}$ (one day before day $\mathrm{t}$ ). It means that closing price on day $\mathrm{t}$ $\left(\mathrm{CP}_{t}\right)$ is higher than its MA on day $t$ when closing price on day $t-1\left(\mathrm{CP}_{t-1}\right)$ is higher than its MA on day $t-1$.

Conversely, sell signal should be presented $\mathrm{CP}_{\mathrm{t}}<\mathrm{MA}_{\mathrm{t}}$ when $\mathrm{CP}_{t-1}>\mathrm{MA}_{t-1}$. When closing price on day $t\left(\mathrm{CP}_{t}\right)$ is lower than its MA on day $\mathrm{t}\left(\mathrm{Ma}_{\mathrm{t}}\right)$ and closing price on day $t-1\left(\mathrm{CP}_{t-1}\right)$ is higher than its MA on day $t-1\left(\mathrm{MA}_{t-1}\right)$, buy signal produced.

Closing price of stock $i$ when buy signal produced on day $x$ is $P_{b, i, x}\left(P_{s, i, x}\right)$. Return of individual. stock using $\mathrm{MA}(n)$ signal on day $x$ presented in equation (4).

$$
\operatorname{Rt}_{\mathrm{MA}(n), I}=\left(P_{s, i, x}-P_{b, i, x}\right) / P_{b, i, x}
$$

Cumulative return of individual stock using $\operatorname{MA}(n)$ stated as $\mathrm{CRt}_{\mathrm{MA}(n), i}$. and average cumulative return of individual stock using $\operatorname{MA}(n)$ stated as $\operatorname{ACRt}_{\mathrm{MA}(n)}$. The first 
hypothesis predicts that $\mathrm{ACRt}_{\mathrm{MA}(n), i}>0$. For the second hypothesis, we expect that $\beta 1>0$. The symbol of $n_{\mathrm{MA}}$ is describe MA length.

$$
\mathrm{ACRt}_{\mathrm{MA}(n)}=a+\beta 1 . n_{\mathrm{MA}}+e
$$

\section{Result and discussion}

This study tests the performance of trend following indicators using 5-day until 100-day EMA to capture EMA usefulness on very short-term to longer trading horizon. Better performance is indicated by the ability of technical analysis to produce positive return (profit). Table 1 provides the profitability of EMA in Indonesian stock market.

Table 1 Profitability of EMA in Indonesian stock market using daily data (January 2, 2008December 29, 2017)

\begin{tabular}{|c|c|c|c|c|}
\hline$n$ & $\begin{array}{c}\text { EMA } \\
\text { periods }\end{array}$ & EMA return (no fee) & $\begin{array}{c}\text { EMA return } \\
\text { (after fee) }\end{array}$ & t-value \\
\hline 50 & 5 & $235.80 \%$ & $-45.47 \%$ & $-5.5800653 * * *$ \\
\hline 50 & 10 & $242.21 \%$ & $-2.79 \%$ & -0.152562 \\
\hline 50 & 15 & $317.50 \%$ & $54.94 \%$ & $1.6077723^{*}$ \\
\hline 50 & 20 & $286.18 \%$ & $64.75 \%$ & $1.9811345 * *$ \\
\hline 50 & 25 & $255.84 \%$ & $66.10 \%$ & $2.245794 * *$ \\
\hline 50 & 30 & $259.04 \%$ & $81.20 \%$ & $2.3636647 * *$ \\
\hline 50 & 35 & $272.36 \%$ & $101.60 \%$ & $2.5752677 * * *$ \\
\hline 50 & 40 & $261.68 \%$ & $101.90 \%$ & $2.6804067 * * *$ \\
\hline 50 & 45 & $257.68 \%$ & $107.72 \%$ & $2.8376788 * * *$ \\
\hline 50 & 50 & $282.07 \%$ & $128.01 \%$ & $2.7636891 * * *$ \\
\hline 50 & 55 & $256.53 \%$ & $120.40 \%$ & $2.9513811 * * *$ \\
\hline 50 & 60 & $229.44 \%$ & $106.87 \%$ & $3.056681 * * *$ \\
\hline 50 & 65 & $236.43 \%$ & $116.08 \%$ & $3.2650597 * * *$ \\
\hline 50 & 70 & $236.53 \%$ & $120.42 \%$ & $3.3081409^{* * *}$ \\
\hline 50 & 75 & $241.31 \%$ & $129.30 \%$ & $3.0087483 * * *$ \\
\hline 50 & 80 & $246.58 \%$ & $135.81 \%$ & $3.2938619 * * *$ \\
\hline 50 & 85 & $236.93 \%$ & $132.42 \%$ & $3.6257737 * * *$ \\
\hline 50 & 90 & $247.61 \%$ & $143.30 \%$ & $3.336042 * * *$ \\
\hline 50 & 95 & $242.04 \%$ & $142.59 \%$ & $3.1203186^{* * *}$ \\
\hline 50 & 100 & $234.92 \%$ & $139.38 \%$ & $3.3179262 * * *$ \\
\hline
\end{tabular}

$*, * *, * * *$ significance at the $10 \%, 5 \%$, and $1 \%$ levels, respectively.

Signals produced by EMA(5) generate $235.8 \%$ for 10 years, but after considering transaction fee, the return is dropped to $-45.47 \%$. EMA(10) also present the same result. Return of EMA(10) is $242.21 \%$ for the same period, but the transaction fee make this strategy gives $-2.79 \%$. Both of indicators do not produce profitable strategy and $H_{1}$ is not 
supported using those methods. Conversely, after using longer duration of EMA, $\mathrm{H}_{1}$ is supported. The results are robust when our findings show that EMA(15) until EMA(100) generate profitable return. Signals from EMA(100) results $139.38 \%$, and it is significant at $1 \% . \mathrm{H}_{1}$ is supported. Using SMA and WMA indicators, our research finds the same results (untabulated). TA using SMA, WMA, and EMA generally produce profitable return when those are applied in Indonesian stock market.

Overtrading degrades the performance of this indicator because of transaction fee. This argument is examined in $\mathrm{H}_{2}$. After processing the data, we find that $\mathrm{H}_{2}$ is also supported. The results are presented in Table 2 .

Table 2 The impact of EMA length to its return (January 2, 2008-December 29, 2017)

\begin{tabular}{lcccc}
\hline & Coefficients & Standard error & $t$-Stat & $p$-value \\
\hline Intercept & 0.297723 & 0.095115606 & 3.130121 & $<0.01$ \\
$n_{\mathrm{MA}}$ & 0.013238 & 0.001588019 & 8.336267 & $<0.01$ \\
F-test & 69.49335 & & & \\
Adjusted $R$ Square & 0.782841 & & & \\
Observations* & 20 & & & \\
\hline
\end{tabular}

*Each observation is based on mean of technical analysis return from fifty stocks for 10 years.

Using average cumulative return based on EMA indicators, we present evidence that after considering transaction fee, longer EMA duration produce higher return and vice versa. This statement is concluded based on p-value of $\mathrm{ACRt}_{\mathrm{MA}(n)}$. So, $H_{2}$ is supported. It can be inferred based on positive coefficient produced by the regression and it is significant at $1 \%$.

Our examination indicates that trend following indicators using SMA, WMA, and EMA produce profitable trading strategies. Using duration from 15 until 100, the findings are robust for MA trading strategy using daily data for 10 years in Indonesian stock market. Investors and investment managers or hedge funds managers can use this strategy to minimise loss or maximise return. Implicitly, stocks price data produce information content for stock traders. This phenomenon represents the weak-form efficient market.

The results contribute to trading strategy studies. By using daily data, our findings indicate that shorter EMA stimulate overtrading. It produces high return, but the profit is eliminated by transaction fee. It implies that stock traders or hedge-fund managers have to use longer EMA to produce optimal return. Conceptually, longer trend following indicators build stronger signals and higher probability of successful signals. These findings confirm that argument.

\section{Conclusion}

This study examines the reliability of TA strategies in generating profits. In a market that tends to be less efficient, as in emerging markets, TA strategies are more profitable than in developed markets. This is because the TA strategy is based on price movements and trading volumes in previous periods which further create buy and sell signals. One of the most widely used TA strategies is the MA trading strategy, that is used in this study. 
Developed from previous studies, in this study MA trading strategy is applied to individual stock instead of market index.

The results of this study show that buy and sell signals resulting from TA strategy generate profits. These results are robust for various TA strategies; which are: MA, WMA or EMA with various durations, i.e., short term (5 days) to long term (100 days). Since MA is a trend following strategy, MA will generate higher profit if traders follow major trends (long-term duration) compared to minor trends (short term duration). The test results prove that MA that is applied by following minor trends generate less profit. Moreover, after considering the transaction fee, MA short duration strategy causes losses. These results indicate that if traders use MA strategy, they must follow major trends, so they do not get caught up with overtrading activity that is contra productive to their investment goals.

This study has implication to professional investors to help them make a better decision by using this MA trading strategy. This study also contributes to international investors for country-picking strategy and they can also use MA trading strategy if they decide to invest in Indonesian stock market.

There are several limitations on this study that also can be developed in future research. First, we only use trend following indicators. Oscillators indicators should be used for future researches. Second, the use of international data will produce more contribution, such as considering Foreign Direct Investment (FDI) factors, political stability and economic growth (Bakar and Afolabi, 2017) and also considering how the correlation of stock exchange across countries, such as between stock exchange in ASEAN countries (Chaiboonsri and Chaitip, 2017). Third, this study can use financial information to interact technical analysis and fundamental information, such as earnings management and corporate strategy (Muktiyanto, 2017).

\section{References}

Bahri (2015) 'The volatility of industrial stock returns and an empirical test of arbitrage pricing theory', Review of Integrative Business and Economics, Vol. 4, No. 2, pp.254-276.

Bakar, N.A. and Afolabi, L. (2017) 'Causality nexus between trade, political instability, FDI and economic growth: Nigeria experience', International Journal of Trade and Global Markets, Vol. 10, No. 1, pp.75-82.

Bessembinder, H. and Chan, K. (1995) 'The profitability of technical trading rules in the Asian stock markets', Pacific-Basin Finance Journal, Vol. 3, No. 2, pp.257-284.

Brock, W., Lakonishok, J. and LeBaron, B. (1992) 'Simple technical trading rules and the stochastic properties of stock returns', The Journal of Finance, Vol. 47, No. 5, pp.1731-1764.

Brown, C. (2012) Mastering Elliott Wave Principle: Elementary Concepts, Wave Patterns, and Practice Exercises, Vol. 124, John Wiley \& Sons, Hoboken, New Jersey, USA.

Chaiboonsri, C. and Chaitip, P. (2017) 'Forecasting methods for safeguarding ASEAN-5 stock exchanges during extreme volatility', International Journal of Trade and Global Markets, Vol. 10, No. 1, pp.123-130.

Fan, J.P. and Wong, T.J. (2002) 'Corporate ownership structure and the informativeness of accounting earnings in east Asia', Journal of Accounting and Economics, Vol. 33, No. 3, pp.401-425.

Fifield, S.G.M., Power, D.M. and Sinclair, C.D. (2005) 'An analysis of trading strategies in eleven European stock markets', The European Journal of Finance, Vol. 11, pp.531-548.

Flanegin, F.R. and Rudd, D.P. (2005) 'Should investments professors join the 'crowd", Managerial Finance, Vol. 31, pp.28-37. 
Gunaasih, S.A.P.P. and Nursasmito, I. (2015) 'The evaluation of non-economic events towards the LQ-45 index in Indonesia stock exchange by using event study method', Review of Integrative Business and Economics, Vol. 4, No. 2, pp.106-120.

Gunasekarage, A. and Power, D.M. (2001) The Profitability of Moving Average Trading Rules in South Asian Stock Markets. Emerging Markets Review, Vol. 2, No. 1, pp.17-33.

McKenzie, M.D. (2007) 'Technical trading rules in emerging markets and the 1997 Asian currency crises', Emerging Markets Finance and Trade, Vol. 43, pp.46-73.

Muktiyanto, A. (2017) 'The effect of corporate strategy on earnings management', International Journal of Trade and Global Markets, Vol. 10, No. 1, pp.37-46.

Murphy, J.J. (1999) Technical Analysis of the Financial Markets: A Comprehensive Guide to Trading Methods and Applications, Pearson Professional Education, Welwyn Garden City, UK.

Pring, M.J. (2014) Study Guide for Technical Analysis Explained, 5th ed., McGraw-Hill, New-York, USA.

Taylor, S.J. (2011) Asset Price Dynamics, Volatility, and Prediction, Princeton University Press, Princetown, New Jersey, USA.

Wong, W.K., Manzur, M. and Chew, B.K. (2003) 'How rewarding is technical analysis? Evidence from Singapore stock market', Applied Financial Economics, Vol. 13, No. 7, pp.543-551. 
$\underline{\text { Home }}>>$ International Journal of Trade and Global Markets

\section{International Journal of Trade and Global Markets}

(2) This journal also publishes Open Access articles

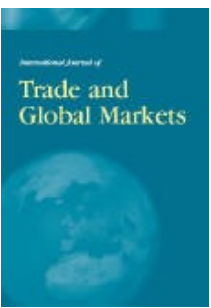

\section{Editor}

Prof. Bruno S. Sergi

ISSN online

1742-755X

ISSN print

1742-7541

4 issues per year

Subscription price

\section{Scopus}

IJTGM fosters discussion on the various interrelationships between economic growth at national and international levels and international trade. The journal will emphasise the implications that trade policy exerts on economic growth and vice versa, as well the role of national governments, international organisations and the business community on related issues of worldwide concern.

\section{Topics covered include}

- International trade

- Economic growth

- The role of international economic organisations in the global economy

- International economic issues

- Interaction between global markets and trade

- Implications of globalisation on markets and trade

- WTO and its policies

- FDI and the international economics

- The role of IT in the process of globalisation

- The importance of growing wealth disparity in trade and management

- The impact of government debts on international trade and management issues

- The role of oil and gas: industry intentions, pricing strategies, etc.

- Trade as determined by currency instability

- Financing trade deficits

More on this journal...

\section{Browse issues}

Vol. 13

Vol. 12

Vol. 11

Vol. 10

Vol. 9

Vol. 8

More volumes...

\& Get Permission

More on permissions

IJTGM is indexed in:

- Scopus (Elsevier).

- Academic OneFile (Gale)
Sign up for new issue alerts

Subscribe/buy articles/issues

View sample issue

Latest issue contents as RSS feed

Forthcoming_articles

Journal information in easy print format (PDF).

Publishing with Inderscience: ethical guidelines (PDF).

Recommend to a librarian (PDF).

Feedback to Editor

Find related journals

Keep up-to-date

Our Blog

Follow us on Twitter

$\underline{\text { Visit us on Facebook }}$

: Our Newsletter (subscribe for free)

. RSS Feeds

Th New issue alerts 

International Journal of Trade and Global Markets (IJTGM) Inderscien... https://www.inderscience.com/jhome.php?jcode=ijtgm 
$\underline{\text { Home }}>$ International Journal of Trade and Global Markets

\section{International Journal of Trade and Global Markets}

(2) This journal also publishes Open Access articles

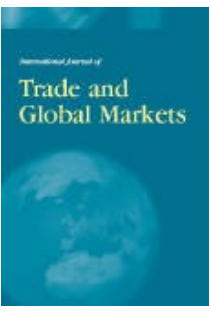

Scopus

IJTGM fosters discussion on the various interrelationships between economic growth at national and international levels and international trade. The journal will emphasise the implications that trade policy exerts on economic growth and vice versa, as well the role of national governments, international organisations and the business community on related issues of worldwide concern.

About this journal

Editorial board

Submitting articles

\section{Editor}

- Sergi, Bruno S., University of Messina, Italy

(bsergi@unime.it)

\section{Associate Editor}

- O'Sullivan, Patrick, Grenoble School of Management, France

\section{Regional Editor Africa}

- Barker, Rachel, University of South Africa, South Africa

\section{Regional Editor Asia}

- Fung, Michael K., Hong Kong Polytechnic University, Hong Kong SAR, China

\section{Regional Editor Europe}

- Matousek, Roman, Nottingham University, UK

\section{Regional Editor USA}

- Adekola, Abel, University of Wisconsin, Stout, USA

\section{Editorial Board Members}

- Bagatelas, William T., University of New York in Prague, Czech Republic

- Belarbi, Abdelhafid, Al Falah University, United Arab Emirates

- Bellavite Pellegrini, Carlo, Catholic University of the Sacred Heart - Milan, Italy

- Bernat, Tomasz, University of Szczecin, Poland

- Bobek, Vito, University of Applied Sciences FH Joanneum, Austria

- Chetvernina, Tatiana, State University Higher School of Economics, Russian Federation

- Crespo, Nuno, University Institute of Lisbon, Portugal

- Esposito, Mark, Harvard University, USA

- Fuentes García, Fernando J., University of Córdoba, Spain

- Grundey, Dainora, Vilnius University, Lithuania

- Hsing, Yu, Southeastern Louisiana University, USA

- Isachenko, Tatiana M., Moscow State Institute of International Relations (MGIMO),
Sign up for new issue alerts

Subscribe/buy articles/issues

View sample issue

Latest issue contents as RSS feed . .

Forthcoming articles

Journal information in easy_print format (PDF).

Publishing with Inderscience: ethical guidelines (PDF).

Recommend to a librarian (PDF)

Feedback to Editor

Find related journals

Keep up-to-date

Our Blog

Follow us on Twitter

Visit us on Facebook

: Our Newsletter (subscribe for free)

. RSS Feeds

New New issue alerts 

International Journal of Trade and Global Markets (IJTGM) Inderscien... https://www.inderscience.com/jhome.php?jcode=ijtgm 
Log in Help Sitemap Linking academia, business and industry through research 


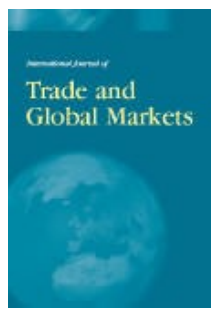

\section{International Journal of Trade and Global Markets}

\section{Vol.13 No.1}

Special Issue on: Interplay Between Financial and Operational Determinants of Growth and Performance in International Markets

Guest Editor: Dr. Arnold C.S. Cheng

Editorial

Pages Title and author(s)

3-10 Measuring trade specialisation of Slovakia on extra EU market Renáta Pitoňáková DOI: 10.1504/IJTGM.2020.104914

11-20 Network-based dynamic capabilities in internationalisation of SMEs: case studies in emerging economy

Anjar Priyono; Siti Nursyamsiah; Baziedy Aditya Darmawan DOI: 10.1504/IJTGM.2020.104907

21-30 Impact of electronic word-of-mouth on brand awareness in the video game sector: a study on Digital Happiness

Sam'un Jaja Raharja; Anindita Citra Dewakanya DOI: 10.1504/IJTGM.2020.104908

31-41 Business model and business model innovation: scholarly incongruence and implications to entrepreneurial firms

Wanniwat Pansuwong DOI: $10.1504 /$ IJTGM.2020.104912

42-51 Validating the adaptive market hypothesis in the Tunisian stock market Adefemi A. Obalade; Paul-Francois Muzindutsi DOI: $10.1504 /$ IJTGM.2020.104906

52-60 Examining trading strategies using trend following indicators for Indonesian stock market

Dedhy Sulistiawan; Felizia Arni Rudiawarni; Yie Ke Feliana DOI: 10.1504/IJTGM.2020.104921

Are emotions exacerbating the recency bias?: An experimental study Felizia Arni Rudiawarni; I. Made Narsa; Bambang Tjahjadi DOI: 10.1504/IJTGM.2020.104913

71-80 Investigating the perception of the elderly on the future of labour market Ha-Yeon Jang: Young-Min Lee DOI: $10.1504 /$ IJTGM.2020.104905

81-88 Fiscal decentralisation and capital expenditure composition of regional government in Indonesia

Imam Ghozali; Khoirunurrofik DOI: 10.1504/IJTGM.2020.104909

The key metrics of traditional market revitalisation from tenant's perspective

Ikeu Kania; Dini Turipanam Alamanda; Fajar Sidiq Adi Prabowo; Abdullah

Ramdhani; Raden Roro Karina Fitria

DOI: 10.1504/IJTGM.2020.104918
Sign up for new issue alerts

Subscribe/buy articles/issues

View sample issue

Latest issue contents as RSS feed $\mathrm{B}$

Forthcoming articles

Journal information in easy print format (PDF).

Publishing with Inderscience: ethical guidelines (PDF)

Recommend to a librarian (PDF)

Feedback to Editor

Find related journals

Keep up-to-date

Our Blog

Follow us on Twitte

Visit us on Facebook

$\vdots \equiv$ Our Newsletter (subscribe for free)

הI) RSS Feeds

Few issue alerts 

International Journal of Trade and Global Markets (IJTGM) Inderscien...

Contact us

About Inderscience

OAI Repository

Privacy and Cookies Statement

Terms and Conditions

Help

Sitemap

(C) 2020 Inderscience Enterprises Ltd. 


\section{GINDERSIENCE PU B L I S HER S Linking academia, business and industry through research}

International Journal of Trade and Global Markets > 2020 Vol.13 No.1

\section{Title: Examining trading strategies using trend} following indicators for Indonesian stock market

Authors: Dedhy Sulistiawan; Felizia Arni Rudiawarni; Yie Ke Feliana

Addresses: Accounting Department, University of Surabaya, Jl. Raya Kalirungkut Surabaya, 60293, East Java, Indonesia ' Accounting Department, University of Surabaya, Jl. Raya Kalirungkut Surabaya, 60293, East Java, Indonesia ' Accounting Department, University of Surabaya, Jl. Raya Kalirungkut Surabaya, 60293, East Java, Indonesia

Abstract: This study aims to examine the reliability of the technical analysis (TA) approach in Indonesian stock exchanges, specifically moving-average trading rule to determine buy/sell signals. Using ten-year data from 2008-2017, our study examines various exponential moving average (EMA) lengths ranging from shorter duration to longer duration. After considering transaction fee, the findings indicate that EMA are profitable indicators in Indonesian stock markets. Furthermore, this study also finds that higher (lower) return are produced by longer (shorter) EMA lengths. These results contribute to international investors for country-picking strategy including trading strategy in emerging markets.

Keywords: technical analysis; exponential moving average; trend following indicator; trading strategy.

DOI: $10.1504 /$ IJTGM.2020.104921

International Journal of Trade and Global Markets, 2020 Vol.13 No.1, pp.52 - 60

Available online: 01 Feb 2020 *

三 Full-text access for editors

Access for subscribers

Purchase this article
Keep up-to-date

Our Blog

Follow us on Twitter

f Visit us on Facebook

非 Our Newsletter (subscribe for free)

ה RSS Feeds

F New issue alerts 